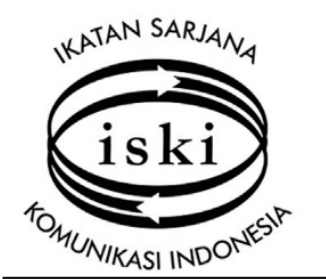

J $U R \quad R \quad N \quad A \quad L$

\title{
Social Cohesion through Social Media as Part of Disaster Information System in Disaster Prone Area
}

\author{
http://dx.doi.org/10.25008/jkiski.v6i2.606
}

\author{
Puji Lestari $^{1}$, Eko Teguh Paripurno ${ }^{2}$, Hikmat Surbakti ${ }^{3}$ \\ ${ }^{1}$ Department of Communication Studies, Faculty of Social and Political Sciences \\ Universitas Pembangunan Nasional "Veteran" Yogyakarta \\ ${ }^{2}$ Faculty of Mineral Technology, Universitas Pembangunan Nasional "Veteran" Yogyakarta \\ Jl. Babarsari No. 2, Yogyakarta 55281 - Indonesia \\ ${ }^{3}$ Ministry of Communication and Information of Karo Regency Local Government \\ Jl. Djamin Ginting No 17, Kabanjahe, Sumatera Utara, 22113, Indonesia \\ Corresponding author: puji.lestari@upnyk.ac.id
}

Submitted: August 10, 2021, Revised: September 12, 2021, Accepted: November 30, 2021

Accredited by Kemristekdikti No. 28/E/KPT/2019

\begin{abstract}
Social media is one of the disaster communication means for social cohesion in information retrieval. However, Karo Regency has limitedly use WhatsApp, Instagram, and Facebook. This study aimed to evaluate social media Instagram and Facebook as part of the disaster information system in disasterprone areas to improve social cohesion in Karo Regency, North Sumatra, Indonesia. This study combined qualitative and quantitative evaluation. Qualitative evaluation steps consist of (1) setting goals; (2) classification; (3) stating structured goals; (4) collecting data; (5) analyzing results of observations and measurements. Based on the evaluation, Instagram has been inactive since April 1 , 2020, and Facebook has been inactive on August 17, 2017, due to the absence of competent human resources (HR). The use of internal WhatsApp groups is due to the unpreparedness in dealing with public comments. Based on a survey in early June 2021 to the Karo community showed that $56.3 \%$ of respondents were familiar with the Karo BPBD social media. The trust level of social media users for social cohesion in the disaster-prone area of Karo Regency was very high at $56.3 \%$. Respondents believed that information conveyed through social media uploads is able to improve social cohesion in dealing with various disasters. This is formed because of the sense of belonging, social trust, generalized reciprocity, and social harmony. This study contributed in the form of BPBD policies in managing social media as an information system to improve social cohesion in the disaster-prone area of Karo Regency. The new findings theoretically added caring in Johnson's Social Cohesion Theory.

Keywords: Karo regency; social cohesion; disaster communication; BPBD social media; disaster information
\end{abstract}

\section{Introduction}

Social media is very popular in various circles as a form of advancement in the use of communication and information technology. Not only the community, but the government also uses social media as a channel of reciprocal communication and information. Social media that are often used by the government are
Twitter, Youtube, and Facebook (Mainka et al., 2014), but it is possible to use other social media such as Instagram. The use of social media is considered to be an alternative for more effective communication between the government and the community (Izzati et al., 2018). This is done by one government in conveying various information, especially 
disasters to the community, namely the Regional Disaster Management Agency (BPBD) of Karo Regency, North Sumatra. The social media used by BPBD Karo Regency are Instagram and Facebook.

Based on observations on May 31, 2021, Instagram and Facebook of Karo Regency BPBD are no longer actively providing disasterrelated information. This observation is supported by the results of the researcher's preinterview with 10 people in Karo Regency who are actively using social media randomly. All informants found it difficult to find the latest information related to the disaster in Karo Regency. In looking for information from other social media accounts, the information is only general, not specific to the Karo Regency. One of the informants stated that the use of social media from official accounts is more reliable than what government officials say, which has not been proven.

The statement is in line with a study by Sutton, Palen, and Shklovski (2008) during the California forest fires in 2007, statements from the organization responsible for not providing important information, so that people use social media in an emergency. The results of a preinterview with Benny the Head of Prevention and Preparedness conducted on June 4, 2021, said that Instagram social media had been inactive since April 1, 2020, while BPBD Karo's Facebook social media had been inactive since August 17, 2017. The reason is that BPBD Karo has difficulty with data problems from human resources (HR) on duty in the field and cannot deal with comments from various parties (journalists or the public). The Karo Regency BPBD is worried that comments thrown on social media will become a boomerang for the Karo Regency BPBD.

HR problems and fears should be faced by Karo Regency BPBD as a government providing information to the public. Karo Regency BPBD must be given training in the form of overall social media management so that they can activate social media and be able to deal with comments wisely in the social media comments column. Karo Regency BPBD must actively use social media because it is considered effective for disseminating various information to various groups. This is in line with a study by Munandar and Suherman (2016) on the use of social media by Ridwan Kamil. The study showed that Ridwan Kamil easily opened communication spaces to collaborate in real terms so that there were no boundaries between the government and the community.

This aims to build Bandung City by solving various problems in order to increase the happiness index. Karo Regency BPBD is expected to use social media to interact and exchange opinions with the Karo Regency community. Information on social media is more easily absorbed by the public because it is shorter, denser, and clearer. This is in line with a study by Ahmad and Samsudin (2017) stating that social media influences knowledge, attitudes, and behavior. Social media plays an important role in channeling opinions. In addition, social media is used by utilizing images, videos, captions, and hashtags, making it easy to search for message content and attract attention (Mohamad \& Han, 2017).

A similar study related to local government social media was conducted by Izzati et al. (2018) stating $79 \%$ of regional office unpopularity in the use of social media is on the Facebook fan page. This happens due to the lack of participation and collaboration between the community and the government so that people are less interested. Suryadharma and Susanto (2017) stated that the interaction between the community and the government occurs due to several factors, namely: (1) the ease of using social media to participate in government social media accounts; (2) the need for accurate information and active government social media accounts; (3) perceived usefulness arising from trust in the government; (4) community activities sharing government information again so that information can reach other people quickly.

Previous studies evaluated the effectiveness of using social media as a communication channel between government and society. There has been no action related to government social media training so that the use of social media is more effective, especially in the case of disasters. The use of social media before, during, and after a disaster has become commonplace in general in society (Robertson et al., 2019). The novelty of this study is the evaluation of Karo Regency BPBD social media using training treatment. This training must be carried out so that Karo Regency BPBD can communicate openly with various parties in real-time. The novelty of the study is also seen from the use of Social Cohesion Theory associated with disaster communication.

\section{Theoretical Frameworks}


Disaster communication provides information to the public on preparedness in terms of action and treatment when a disaster occurs (Lestari, 2018). Disaster communication is a communicative interaction to reduce disaster risk and increase community responsiveness (Haddow \& Haddow, 2009). Disaster communication aims to gain trust, attention, increase awareness, and educate the public to build disaster resilience, as well as build social cohesion (Prayoga, 2020). Disaster communication is needed to create a disasterresilient community in surviving disaster threats (Lestari et al., 2020).

Disaster communication carried out by Karo Regency BPBD is considered to be still less visible from the lack of information on social media. This is in line with a study by Fahriyani, Harmaningsih, and Yunarti (2019) on Twitter used by the National Disaster Management Agency (BNPB) to disseminate disaster information from pre-disaster, emergency response, and post-disaster. Activities performed with social media are educating the public, providing information on disaster-prone maps, determining disaster status, evaluating, and recovering and development.

A study on disaster communication by Prayoga (2020) discussed disaster communication by President Jokowi by utilizing social media. The study showed that Jokowi has used disaster communication by actively providing information on COVID-19 such as handling policies and condolences via Twitter since January 1, 2020. Unfortunately, this was not carried out by disaster communication at the beginning of COVID-19, so as to reduce casualties. This evidence makes it clear that disaster communication before, and during, is critical for community resilience and recovery (Moorthy et al., 2018).

A study on disaster communication using social media by Finau, Tarai, Varea, Titifanue, and Kant (2018) found out that before a disaster occurs, people use social media to provide and receive information related to Tropical Cyclone Winston, and when a disaster occurs, people use social media to share experiences accompanied by images of Cyclones so hashtags appear on social media to make it easier to find information related to the disaster occurred. Disaster communication carried out by the community using social media is considered active, so Karo Regency BPBD must utilize social media because social media connects various networks quickly and widely. Karo
Regency BPBD can also use hashtags such as \#BPBDKaro, \#COVID-19Karo, \#KomunikasiBencana, and other hashtags to make searching easier.

Another study by Syarifah, Poli, Ali, Rahmat, and Widana (2020) stated that BPBD in addition to being tasked with disaster management must also manage disaster communication from data and information obtained in order to create effective communication by utilizing social media. The study showed that social media related to disaster communication and information is very important to build and form a resilient society. Karo Regency BPBD is required to carry out disaster communication through social media in order to create an interconnected society among community members to survive disasters and build social cohesion.

Social cohesion is the ability to bond, harmonize, and survive among people (Johnson, 1994). People feel a sense of belonging among certain members as well as values close to other members (Bakar, 2017). In this study, Karo Regency BPBD must create a safe environment for the community from disasters to fulfill the goals and needs of the Karo Regency community. This is in line with a study by Faisal dan Nain (2018) stating that social cohesion is created simultaneously with the emergence of love and the interaction between community members dominated by cooperation and having goals interrelated with one another. Karo Regency BPBD in creating social cohesion must include several things based on Harpham, Grant, dan Thomas (2002), namely: (1) a sense of belonging between community members in Karo Regency to meet life goals; (2) social trust created by Karo Regency BPBD to encourage the effectiveness of community life in social processes; (3) generalized reciprocity conducted by Karo Regency BPBD related to the community; and (4) social harmony arising from BPBD, community, and other groups in Karo Regency for swift and rapid disaster management.

Based on this background, this study provides recommendations for social media management policies for Karo Regency BPBD. The purpose of this study was to evaluate social media Instagram and Facebook as part of a disaster information system in vulnerable areas to increase social cohesion in Karo Regency.

\section{Material and Methodology}

This study is an evaluative study with qualitative and quantitative data collection 
techniques. Evaluation study methods are usually used qualitatively. This study added a quantitative evaluation. The subjects of this study were all the leadership and staff of Karo Regency BPBD as many as 20 people. The object of this study was social media Instagram and Facebook as part of a disaster information system. This study used an evaluation method oriented to program objectives by emphasizing the objectives of the program set. The evaluation was carried out continuously to check, observe, and measure the extent to which the objectives of this study have been achieved in the program implementation process. The steps of the qualitative evaluation process consists of:

(1) set the program objectives that is to activate the social media like Instagram and Facebook Karo Regency BPBD as part of the disaster information system in vulnerable areas to increase social cohesion in Karo Regency;

(2) classify the objectives such as activating Instagram and Facebook as part of a disaster information system in vulnerable areas to increase social cohesion in Karo Regency, North Sumatra;

(3) identify the objectives in a structured statement carried out before the FGD through pre-observation and pre-interview;

(4) Data collection was carried out at Karo Regency BPBD by: (a) Perform the observation of social media Instagram and Facebook Karo Regency BPBD viewed from the aspects: public knowledge regarding social media of Karo Regency BPBD, community attitudes to respond the social media of Karo Regency BPBD, and community behavior after an interaction with the Karo Regency BPBD social media; (b) the online survey using Google Form conducted with the community in Karo Regency randomly as many as 50 people.

The quantitative evaluation process utilizes questions as seen in Table 1. The indicators used in this study refer to social cohesion that is a sense of belonging, social trust, generalized reciprocity and cooperation, and social harmony. Each indicator has three to six questions related to these indicators to generate an effective evaluation of Karo Regency BPBD social media; (c) interviews were conducted with the Chief Executive of Karo Regency BPBD and Head of Prevention and Preparedness. Mr. Ginting as members of social media that Karo Regency BPBD used; (d) Focus Group Discussion (FGD) related to the evaluation of disaster communication through the Karo BPBD social media by inviting 20 people consisting of the Chief Executive, Echelon III, IV officials, and staff within the Karo Regency BPBD. The data collected through the FGDs included: information on the things that happened on Karo Regency BPBD's social media, information on official Karo Regency BPBD websites, information on the characteristics of good social media, and procedures for responding to the public on social media; and (e) documentation of various observation documents, surveys, interviews, and FGDs related to the Karo BPBD social media evaluation;

(5) analyze data from observations or measurements, namely data that has been collected and then analyzed using: (a) logical methods, namely judging based on rational analysis, and assessing the circumstances that occurred during the evaluation and training of Karo Regency BPBD social media by prioritizing logical considerations; (b) empirical method, namely by performing study conclusions based on data and facts in the field that describe the achievement of program objectives. The conclusions are the study results that become the essence of study in the form of Karo Regency BPBD policies in managing social media activities as the information system to increase social cohesion in disaster-prone areas of Karo Regency.

Table 1. Indicator of Social Cohesion

\begin{tabular}{|c|c|c|}
\hline No & Indicators & Question \\
\hline \multirow{5}{*}{1} & \multirow{5}{*}{ Sense of Belonging } & $\begin{array}{l}\text { If a disaster occurs, is the BPBD social media interesting for finding the } \\
\text { information you need? }\end{array}$ \\
\hline & & $\begin{array}{l}\text { Is the content of social media messages uploaded by BPBD interesting } \\
\text { to you? }\end{array}$ \\
\hline & & Are you interested in interacting through BPBD social media? \\
\hline & & Have you ever interacted through BPBD social media? \\
\hline & & $\begin{array}{l}\text { Are there activities in the BPBD social media to help each other? } \\
\text { Fundraising or other assistance? }\end{array}$ \\
\hline
\end{tabular}




\begin{tabular}{|c|c|c|}
\hline No & Indicators & Question \\
\hline & & $\begin{array}{l}\text { Is the content of the message uploaded by BPBD in accordance with the } \\
\text { prevailing norms in the Karo community? } \\
\text { Do you like the content of messages uploaded by BPBD social media? } \\
\text { Do you agree with the content of the message uploaded by BPBD social } \\
\text { media? } \\
\text { Do you see BPBD fulfilling its obligation to upload disaster messages? }\end{array}$ \\
\hline \multirow{4}{*}{3} & \multirow{4}{*}{$\begin{array}{l}\text { Generalized } \\
\text { Reciprocity and } \\
\text { Cooperation }\end{array}$} & $\begin{array}{l}\text { As a Karo community, have you ever helped other people in need } \\
\text { through BPBD social media? }\end{array}$ \\
\hline & & $\begin{array}{l}\text { As a Karo community, have you ever asked for help from other people } \\
\text { through BPBD social media? }\end{array}$ \\
\hline & & $\begin{array}{l}\text { Have you ever seen messages about providing assistance to others } \\
\text { through BPBD social media? }\end{array}$ \\
\hline & & $\begin{array}{l}\text { If there are people who need assistance through BPBD social media, } \\
\text { would you be willing to help? }\end{array}$ \\
\hline \multirow{4}{*}{4} & \multirow{4}{*}{ Social Harmony } & $\begin{array}{l}\text { Does the Karo Regency BPBD social media provide a spirit of } \\
\text { cooperation in disaster management? }\end{array}$ \\
\hline & & $\begin{array}{l}\text { Does Karo Regency BPBD social media direct fast and swift action in } \\
\text { handling disasters in Karo? }\end{array}$ \\
\hline & & $\begin{array}{l}\text { Does Karo Regency BPBD social media establish mutual cooperation } \\
\text { between people in disaster management? }\end{array}$ \\
\hline & & What kind of form is the cooperation? \\
\hline
\end{tabular}

Source: Processed Data (2021)

\section{Results and Discussion}

This study shows a meeting point in the form of social media management policies for Karo Regency BPBD through FGDs. The Karo Regency BPBD social media evaluation activity is a continuation of the June 8, 2021 FGD activity held at the Karo Regent Office regarding the creation of an information and communication system for disaster management in Karo Regency. The Regent of Karo, Cori Sebayang, gave an excellent response when he heard the report on the evaluation of social media and the creation of the information and communication system for the Karo BPBD. Cory Sebayang agreed that Karo Regency BPBD should develop and actively provide information to the public through social media. The FGD process was carried out on June 11, 2021 that was attended by the Head of BPBD, 20 structural officials and social media managers of the Karo Regency BPBD along with the study team (Figure 1).

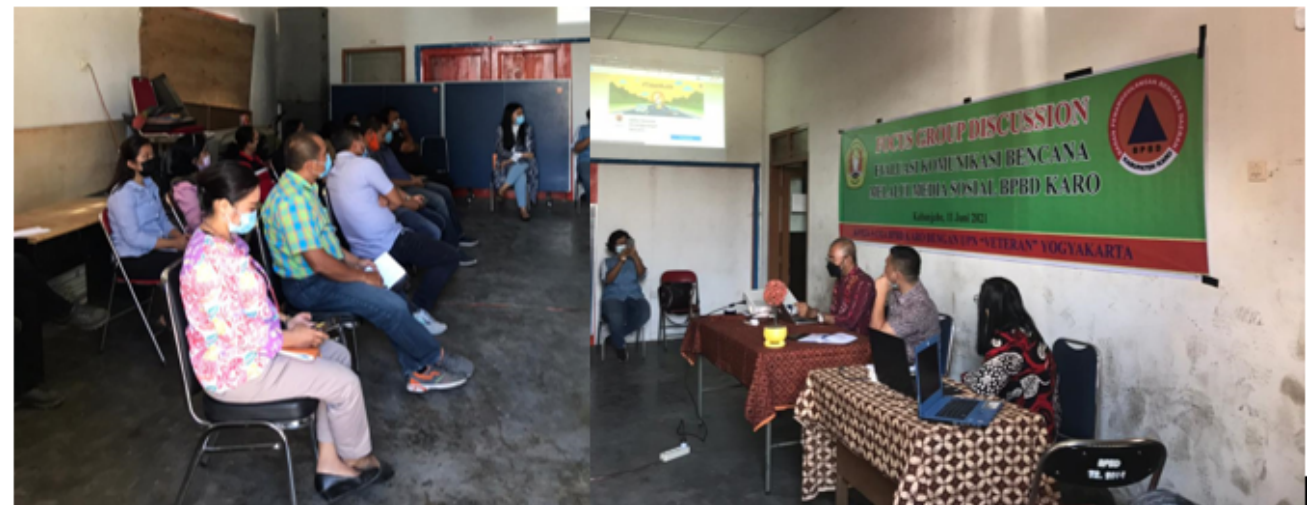

Figure 1. FGD of Evaluation of Disaster Communication through Karo Regency BPBD social media Source: Processed Data (2021)

Figure 1 shows the FGD was carried out starting by providing the overview of good social media managed by the Karo Regency BPBD government, good social media training to improve the reputation of Karo Regency BPBD and a place for communication with the community. The Karo Regency BPBD still used
WhatsApp groups but it is internal, namely the BPBD employee group, BPBD Civil Servant, Gunung Sinabung, Langsi, COVID-19, or the Rapid Reaction Team (TRC) or Rapid Reaction Unit (URC). The group did not cover the entire community due to the limited capacity of members, so that there was a disaster that the 
community did not get information directly and quickly and is responsive. Karo Regency BPBD realizes that the use of social media as a communication bridge is very important.

"Social media is very important for the current situation but Karo BPBD social media was managed by internship students, since internship students graduated, the use of social media was no longer active. So, the current problem regarding data very difficult, and in the past we uploaded the activities but received negative comments, we could not deal with these comments, another factor was difficult to expect data from the colleague in the field. They did not immediately report the incident in the field, but they immediately returned to their homes. If they are asked the data related to victims or incidents to be uploaded, the answer us definitely no, because they do not record anything " (Benny, Head of Planning and Preparedness of Karo Regency BPBD, 11 July 2021).

Researchers advised on the things feared by Karo Regency BPBD in managing social media such as: (1) the data that is difficult to be collected may use the online form to fill out report data in the field of disaster events in Karo Regency, thus field workers do not need to go to the office anymore and can fill out the reports on a mobility basis; (2) dealing the comments from social media done by conveying kindness and good information, providing honest, factual information (finding facts in the field, references, discussing with other members or checking facts through the MAFINDO website), and must be answered (this is better answered than not answered at all), and it needs answering carefully but calmly due to different knowledge owed by people. Another input is to filter the comments or responses in the social media column; (3) confusion in filling out the content that can be circumvented by uploading policies related to disasters, for example, the policy on the Mount Sinabung area map, the posts for Mount Sinabung, the COVID-19 policy, and the rules established during COVID19 , or the DESTANA work program. Karo Regency BPBD can also re-upload programs carried out by packaging the messages in an attractively for providing the comparisons of results from past and present work programs. It is considered more effective because it looks like progress from the Karo Regency BPBD work program.
"I'm actually pessimistic about this social media, I want Karo BPBD social media to be reactivated, I want the update, but the problem is the collagues do not support it. Another obstacle is there is no field that handles social media related to the data that needs to be used to inform the disaster. The problems that arise during monitoring must be faced and overcome; they cannot continue to run away" (Ginting, Member of the Planning and Preparedness Division of Karo BPBD, 4 July 2021).

Karo Regency BPBD wants to update regarding the implementations in disseminating disaster information to the public. The reform was realized by the Head of Karo Regency BPBD with the formulation of new policies set for the community. It is proved that the Head of Karo Regency BPBD appreciates and welcomes the activities that have been carried out by researchers to the Karo Regency BPBD employees. Follow-up evaluation in the form of treatment in the use of Karo Regency BPBD social media for disaster management was well received by BPBD employees.

"We have carried out the training well and
seen the results of the survey on our social
media such as Instagram and Facebook. A
lot of input from the training and the results
of the evaluation of social media. I really
expect that we can implement it, now as
BPBD administrators we form a new
organization to manage social media. I
undertake to reactivate the Karo BPBD
social media as a more effective Karo
community disaster communication media.
I appointed Pak Surbakti as PIC for
prevention and preparedness" (Juspri
Nadeak, Head of Karo Regency BPBD, 11
June 2021)

The Chief Executive of BPBD emphasized that all valid disaster-related information submitted by trusted sources had an impact on the community. It is the caring of the Karo Regency BPBD to upload information on social media in order to have a good impact on the community regarding disaster management. The basic of this task requires the important role of the person in chaning the field in the Karo Regency BPBD to always collect documentary evidence of each activity so that it is uploaded on the Karo Regency BPBD social media and provides real benefits for the 
community. The Head of the Karo Regency BPBD had taken the right step by issuing a new policy to form a Karo Regency BPBD social media management team.

Before training, researchers conducted a survey through an online Google Form that was conducted randomly by 50 people, 21 women, and 29 men. The results of these respondents became input to the Karo Regency BPBD for social media training. All respondents had social media accounts that consist of Facebook, Instagram, Twitter, Youtube, TikTok, Hago, Snack Video, and WhatsApp. There were 50 respondents, $56.3 \%$ were familiar with the Karo Regency BPBD social media. It is due to the inactivity of the Karo Regency BPBD in optimizing the use of social media as a way of communication and information in Karo Regency. The processed data that $100 \%$ of the $56.3 \%$ known trusted the social media of Karo Regency BPBD. The trust must be held by the Karo Regency BPBD because trust is not easy to obtain, especially since social media has not been active in providing important information to the Karo Regency community.

The results of the survey related to social media to increase social cohesion in disasters including the elements such as:

(1) The feeling of togetherness felt by the people of Karo Regency feels accepted, valued, and involved in activities on the Karo Regency BPBD social media (Figure 2).

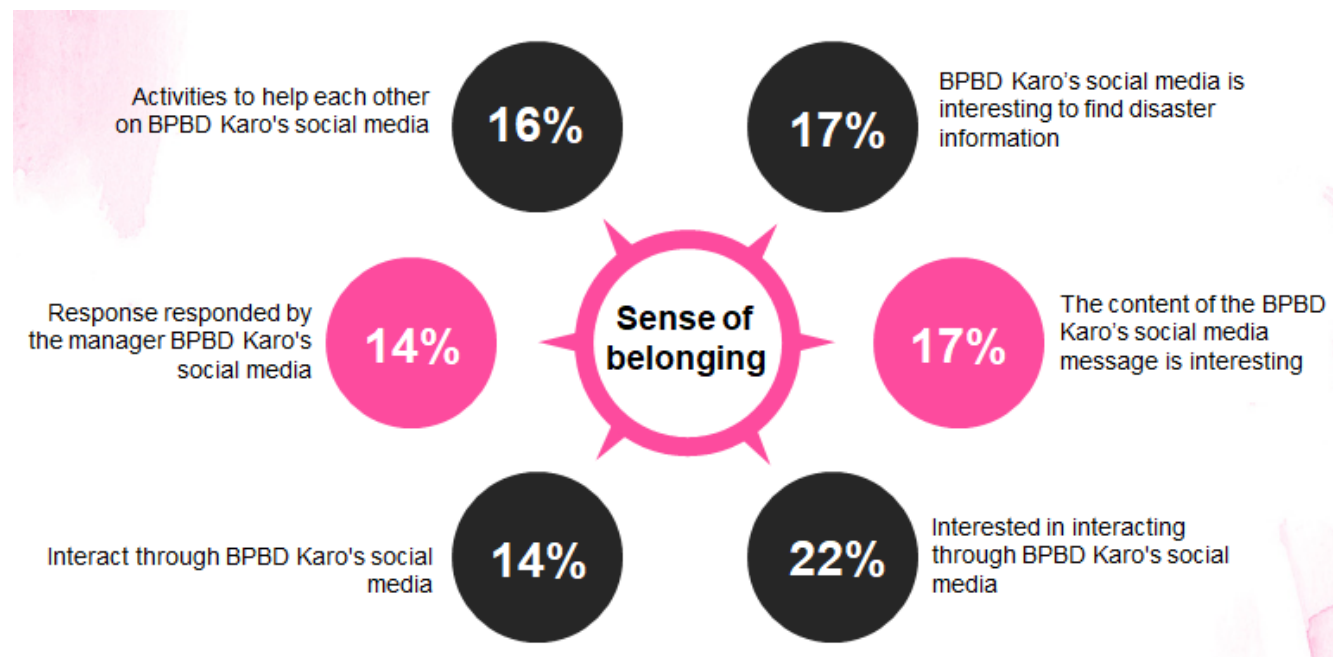

Figure 2. Sense of belonging

Source: Researcher's analysis results (2021)

Figure 2 shows the highest percentage that was $22 \%$ interested in interacting through social media of Karo Regency BPBD. It is due to the desire of the community to be involved in the information or communication process to support the social media account. People's interest in interacting is also influenced by the activity of social media. Social media activity can be seen by checking the last status of uploading information and the usefulness of the content. Activeness is also seen from the interactions carried out by Karo BPBD social media such as replying to comments or reposting information from other people.
Unfortunately, the smallest percentage of $14 \%$ is found in the response that is responded to by the manager and interacts through social media of the Karo Regency BPBD. From the evaluation can be concluded that BPBD of Karo Regency is fearful of responding the public comments on social media;

(2) The social trust generated by BPBD of Karo Regency social media was highly valued by the community. It can be seen in Figure 3 that showed $18 \%$ of social trust arose because people trust and agree with the content of information uploaded on social media and it is in accordance with applicable norms. 


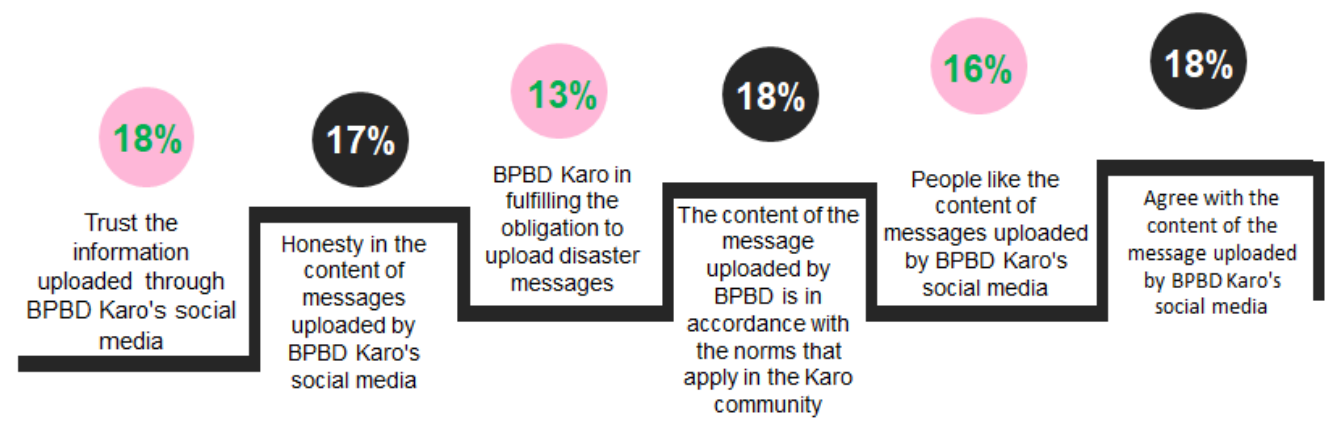

Figure 3. Social Trust

Source: Researcher's analysis results (2021)

The high level of public social trust in social media of the Karo Regency BPBD can be caused by several factors among others: having clearly verified the ownership of the social media account that was owned by the Karo Regency BPBD; the information submitted on the social media account contains good information in accordance with the facts thatoccurred thereby in increasing the trust to encourage the effectiveness of people's lives in carrying out social processes related to disasters;

(3) The element of reciprocal cooperation is carried out so that the people of Karo Regency remain attached to the Karo Regency BPBD social media which together maintain unity to achieve goals. The purpose of establishing social media in addition to provide disaster information can also be used to help the community through online fundraising.

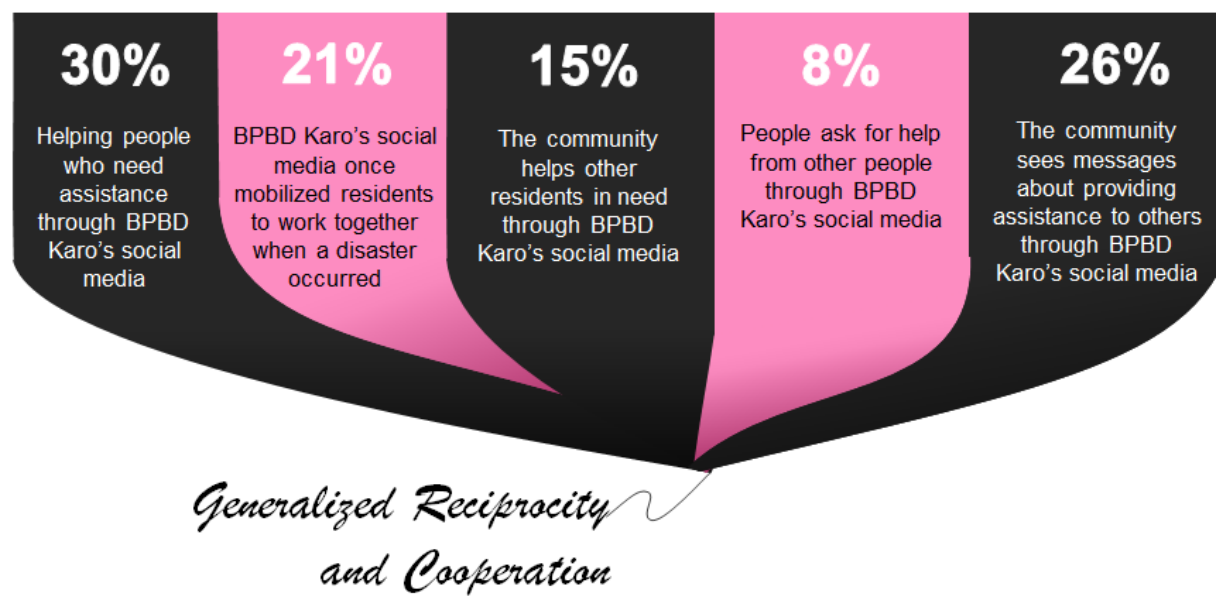

Figure 4. Generalized Reciprocity and Cooperation Source: Researcher's analysis results (2021)

In Figure 4, 30\% of the community helps others who need assistance through Karo Regency BPBD social media. The ease of helping people in other places through social media is considered more effective because people do not need to think to deliver the aids. Karo Regency BPBD in raising funds or assistance must have had the right subject. Only the smallest percentage of $8 \%$ in the community ask for help for others through Karo Regency BPBD social media. This is due to the inactivity of the social media account to interact so that people immediately think that asking for help is a waste of time because there is no certainty of a response time;

(4) Social harmony has been established by Karo Regency BPBD social media seen from the rapid and agile disaster management by utilizing cooperation from other groups such as TRC or URC, Social Welfare Personnel (Tagana), and others to achieve goals such as evacuating victims, distributing aid, and other social activities to achieve the social goals. 


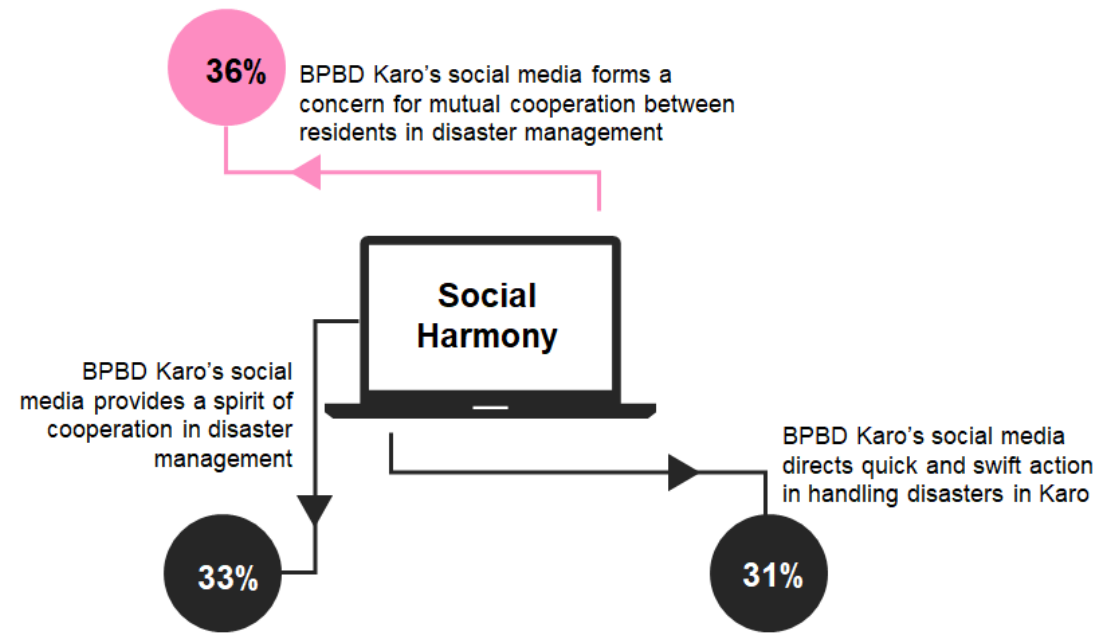

Figure 5. Social Harmony

Source: Researcher's analysis results (2021)

Figure 5 shows that all indicators of social harmony were good with a score of $36 \%$ to form a mutual caring for cooperation between people, $33 \%$ to provide a spirit of cooperation, and $31 \%$ to direct quick and swift action in disaster management and handling in Karo Regency BPBD social media. This can be caused by a sense of humanity for a better life, the emergence of tolerance with others, and the desire to share in order to ease the suffering. Small things performed for social harmony can give life spirit to disaster survivors. Survivors feel a sense of belonging and caring for themselves to continue living.

The researchers found out that $56.3 \%$ were familiar with Karo Regency BPBD social media and had confidence in the information uploaded through Karo Regency BPBD social media. This is proof that Karo Regency BPBD social media can be used to establish communication between the community and the government. Utilization of social media as a tool to convey up-to-date information related to disasters occurring in certain areas, distribute disaster assistance, and convey approved policies, work programs, and local government strategies in disaster management. The effective function of social media is also used as a channel to mobilize and provide assistance to those in need.

This study found out that the use of training treatment to evaluate Karo Regency BPBD social media had a big impact on Karo Regency BPBD. After the training, a policy formulation was obtained to re-manage Karo Regency BPBD social media as part of a disaster information and communication system to improve social cohesion. Social cohesion can support social activities by utilizing Karo Regency BPBD social media. Social cohesion in social media is important because it can affect disaster-affected people through various mechanisms in social media, such as health, strength, or enthusiasm for life. Social media has a considerable influence in creating social cohesion before, during, and after a disaster. This is in line with a study by Samarakoon dan Abeykoon (2018) stating that social cohesion after a disaster is important so that social cohesion is created through social media relating survivors and groups that form each other to find the strengths.

This study added the element of caring in the existing Social Cohesion Theory. The Karo Regency community has increased social cohesion in dealing with disasters by interrelated with each other to achieve the goal, namely being resilient to disasters and meeting the needs of people. This is in line with Social Cohesion Theory by Johnson (1994) to be mutually bound, to survive, to be in harmony among members of society. Increasing social cohesion in communication is formed based on the elements, namely sense of belonging, social trust, generalized reciprocity, and social harmony. The people of Karo Regency feel they have a purpose and enjoy every interaction between community members. The community feels that they have a synergistic relationship with Karo Regency BPBD to undergo a social process. This is in line with a study by Agung, Fu'ady, dan Surur (2018) stating that the social cohesion in the group has the power to actively participate in each other, be cohesive, tied together, and have goals. Research conducted by Kankanamge, Yigitcanlar, dan Goonetilleke (2020) related to patterns and behavior of disaster communication on social media.

The results of this study indicate that: (1) Social media acts as a trusted source to receive 
and impart knowledge that is disseminated to the public; (2) The use of images, maps, or animations in posting on social media can increase the level of community engagement; and (3) The purpose of posting on social media is to get attention from other communities and raise awareness of the situation. Karo Regency BPBD social media can also reduce disaster risk because disaster information is always communicated to all Karo Regency community.

Disaster communication created by Karo Regency BPBD is very important for people who are better prepared in dealing with disasters. The information conveyed is given accurately to the community related to disasters, a government obligation to be able to provide knowledge, attitudes, behavior, and actions. This is in accordance with the definition of disaster communication showing that communicative interaction reduces disaster risk and increases community responsiveness. Disaster communication shows that disasterresilient communities need to be provided with information on preparedness for action and treatment before, during, and after disasters (Lestari, 2018).

Disaster communication becomes a disaster management effort because it is considered to be able to: (1) assess disasters occur; (2) facilitate community behavior in managing disasters occur, and (3) have disaster management efforts (Spialek \& Houston, 2018). The success of a resilient community can become a valuable value for Karo Regency BPBD because it can show the performance of Karo Regency BPBD related to the socialization of disaster communication to the community. Disaster socialization to the community is able to take advantage of social media because it is considered to be coordinated and faster and easily accessible for people in need. A study by Lovari dan Bowen (2020) showed that disaster communication through social media must be supported by highly dedicated and competent managers, so that the information disseminated is accurate and in accordance with the ethics of communication and disaster information.

Evaluation of Karo Regency BPBD social media using qualitative and quantitative methods are interrelated. This shows that the evaluation of the qualitative method is strengthened by the quantitative results. This statement is evidenced by the results of the evaluation of the qualitative method stating that the Karo Regency BPBD does not have the courage to respond to the negative comments, so it is shown that the evaluation results using the quantitative method that only $14 \%$ of the responses responded to interacting on social media of the Karo Regency BPBD. The information provided on social media must be certain so that the community can take strategic steps to deal with various disasters that occur.

The researcher can be concluded that social media is a place to reveal Karo Regency BPBD daily activities to the Karo Regency community so that the community takes the initiative in disaster management such as monitoring the situation, integrating emergency planning, disseminating information, creating social cohesion, and providing answers to information and communication needs of the local community. Social cohesion is very important before, during, and after a disaster with social media as a liaison with the community. This study proved that Social Cohesion Theory has an important relationship with disaster communication to empower survivors to achieve life goals through social media.

The new findings in this study add aspects of social cohesion not only four elements, but one element can be added, namely caring. In disaster practice, community-tocommunity communication is aimed at helping survivors cope with disaster risk reduction. The caring in this study is manifested through communication activities in fundraising, being involved as volunteers, and providing various information through writing on social media that moves people to care for each other. This study also resulted in a policy for Karo Regency BPBD stating the ability to activate Karo Regency BPBD social media in improving social cohesion in disaster communication more effectively.

\section{Conclusion}

This study evaluated the social media of Karo Regency BPBD according to objectives. The results showed that $56.3 \%$ of respondents were familiar with the social media of Karo Regency BPBD and $100 \%$ trusted the information conveyed by Karo Regency BPBD with $24 \%$ sense of belonging, $29 \%$ of social trust, $20 \%$ of generalized reciprocity and cooperation, and $27 \%$ of social harmony. The researcher found that disaster communication and social cohesion were indispensable and interrelated with social media used by BPBD of Karo Regency. Communities with the knowledge related to the disaster, maps of disaster areas, and the ways to overcome it 
have the potential to protect themselves and they last longer. There is an important relationship between disaster communication and social media to create social cohesion. The researcher recommends that the government is responsible for social cohesion of disaster communication through training treatment. The training treatment had a good impact on social media managers to actively provide information.

Researchers also recommend the government to make social media management policies to provide information. The researcher also recommends that the government make a social media management policy as part of an integrated disaster information system that is designed together between researchers and the Karo Regency BPBD. The theoretical implication is that social cohesion theory can be used to dissect the cohesion problem in disaster communication by adding four aspects (Based on Johnson) and the caring aspect as a novelty of this study.

\section{Acknowledgement}

The researcher would like to thank you to the Directorate of Research and Community Service, Ministry of Research and Technology/National Research and Innovation Agency who funded this research through Higher Applied Research and Higher Education in 2021 and the Institute for Research and Service to the Community of the Universitas Pembangunan Nasional "Veteran" Yogyakarta, the research subjects were the Head and member of Karo Regency BPBD with the Regional Government Work team, Regional Work Units (SKPD), Non-Governmental Organisation (NGOs), research assistants.

\section{References}

Agung, Y. R., Fu'ady, M. A., \& Surur, M. (2018). Kohesi Sosial dalam Membentuk Harmoni Kehidupan Komunitas Yusuf Ratu Agung Muh. Anwar Fu'ady Miftahus Surur. Jurnal Psikologi Perseptual, 3(1), 37-43.

Ahmad, F., \& Samsudin, D. (2017). Kebergantungan Media Sosial Terhadap Isu Arab Spring Dalam Kalangan Khalayak di Malaysia (Arab Spring and Media Dependency Amongst Malaysian Audience). Jurnal Komunikasi: Malaysian Journal of Communication, 33(1), 423-437. https://doi.org/10.17576/jkmjc-20173301-28
Bakar, H. A. (2017). Explaining cohesion linkages in workgroups: The cooperative communication in collectivism and high power distance workgroup context. Jurnal Komunikasi: Malaysian Journal of Communication, 33(3), 157-177. https://doi.org/10.17576/jkmjc-20173303-10

Fahriyani, S., Harmaningsih, D., \& Yunarti, S. (2019). Penggunaan Media Sosial Twitter Untuk Mitigasi Bencana Di Indonesia. Journal Sosial dan Humaira, 4(2), 56-65. Diambil dari https://journals.upiyai.ac.id/index.php/ikraithhumaniora/article/view/556

Faisal, M., \& Nain, U. (2018). Implikasi Program Dana Desa terhadap Kohesi Sosial di Desa Tamalate Kabupaten Takalar. Sosiohumaniora, 20(3), 222230.

https://doi.org/10.24198/sosiohumaniora .v20i3.16070

Finau, G., Tarai, J., Varea, R., Titifanue, J., \& Kant, R. (2018). Social Media and Disaster Communication A case study of Cyclone Winston. Pasific Journalism Review, 24(1), 123-137. https://doi.org/10.24135/pjr.v24i1.400

Haddow, G. D., \& Haddow, K. S. (2009). Disaster Communications in a Changing Media World. United Kingdom: Elsevier.

Harpham, T., Grant, E., \& Thomas, E. (2002). Measuring social capital within health surveys: key issues. Health policy and planning, 17(1), 106-111. https://doi.org/10.1093/heapol/17.1.106

Izzati, A. N., Pratama, A., Aristamy, I. M., Najwa, N. F., \& Rakhmawati, N. A. (2018). Kategorisasi Jenis Interaksi Pemerintah dan Masyarakat serta Popularitas Media Sosial Pemerintah Daerah. Jurnal Sistem Informasi, 14(1), 1-8. https://doi.org/10.21609/jsi.v14i1.567

Johnson, P. D. (1994). Teori Sosiologi: Klasik dan Modern, Jilid I dan II, (Terjemahan). Jakarta: Gramedia.

Kankanamge, N., Yigitcanlar, T., \& Goonetilleke, A. (2020). How engaging are disaster management related social media channels? The case of Australian state emergency organisations. International Journal of Disaster Risk Reduction, 48(December 2019), 101571. https://doi.org/10.1016/j.ijdrr.2020.1015 71

Lestari, P. (2018). Komunikasi Bencana: Aspek 
Penting Pengurangan Risiko Bencana. Yogyakarta: PT. Kanisius.

Lestari, P., Ritonga, R., Ruliana, P., \& Barus, C. C. B. (2020). Disaster Communication Uses Field Training Exercise Simulation as an Important Aspect of Disaster Risk Reduction. Jurnal Komunikasi: Malaysian Journal of Communication, $36(24)$, 166-186. https://doi.org/doi.org/10.17576/JKMJC2020-3601-10

Lovari, A., \& Bowen, S. A. (2020). Social media in disaster communication: A case study of strategies, barriers, and ethical implications. Journal of Public Affairs, 20(1), $1-9$. https://doi.org/10.1002/pa.1967

Mainka, A., Hartmann, S., Stock, W. G., \& Peters, I. (2014). Government and social media: A case study of 31 informational world cities. Proceedings of the Annual Hawaii International Conference on System Sciences, (January), 1715-1724. https://doi.org/10.1109/HICSS.2014.219

Mohamad, E., \& Han, W. C. (2017). Opinion leaders communicating on plastic surgery: An analysis of Instagram postings by selected social media celebrities. Jurnal Komunikasi: Malaysian Journal of Communication, 33(1), 261-279. https://doi.org/10.17576/jkmjc-20173301-18

Moorthy, R., Benny, G., \& Gill, S. S. (2018). Disaster Communication in Managing Vulnerabilities. Jurnal Komunikasi, Malaysian Journal of Communication, 34(2), 51-66. https://doi.org/10.17576/jkmjc-20183402-04

Munandar, H., \& Suherman, M. (2016). Aktivitas Komunikasi Pemerintahan Ridwan Kamil di Media sosial. Jurnal Hubungan Masyarakat, 2(1), 423-430. Diambil dari http://karyailmiah.unisba.ac.id/index.php /humas/article/viewFile/3270/pdf

Prayoga, K. (2020). How Jokowi Communicates with The Public during COVID-19 Crisis: An Analysis of Tweets on Twitter. Jurnal Komunikasi: Malaysian Journal of Communication,
$36(2)$, 434-456. https://doi.org/10.17576/JKMJC-20203602-26

Robertson, B. W., Johnson, M., Murthy, D., Smith, W. R., \& Stephens, K. K. (2019). Using a combination of human insights and 'deep learning' for real-time disaster communication. Progress in Disaster Science, $\quad 2, \quad 100030$. https://doi.org/10.1016/j.pdisas.2019.100 030

Samarakoon, U., \& Abeykoon, W. (2018). Emergence of Social Cohesion after a disaster: (With reference to two flood affected locations in Colombo DistrictSri Lanka). In Procedia Engineering (Vol. 212, hal. 887-893). Elsevier B.V. https://doi.org/10.1016/j.proeng.2018.01. 114

Spialek, M. L., \& Houston, J. B. (2018). The Development and Initial Validation of the Citizen Disaster Communication Assessment. Communication Research, 45(6), 934-955. https://doi.org/10.1177/00936502176975 21

Suryadharma, B., \& Susanto, T. D. (2017). Faktor Penerimaan Media Sosial Instansi Pemerintah di Indonesia. INTEGER: Journal of Information Technology, 2(2), 1-10. Diambil dari http://ejurnal.itats.ac.id/index.php/intege r/article/view/174

Sutton, J., Palen, L., \& Shklovski, I. (2008). Backchannels on the front lines: Emergent uses of social media in the 2007 Southern California Wildfires. In Proceedings of ISCRAM 2008 - 5th International Conference on Information Systems for Crisis Response and Management (hal. 624-631).

Syarifah, H., Poli, D. T., Ali, M., Rahmat, H. K., \& Widana, I. D. K. K. (2020). Kapabilitas Badan Penanggulangan Bencana Daerah Kota Balikpapan dalam Penanggulangan Bencana Kebakaran Hutan dan Lahan. NUSANTARA: Jurnal Ilmu Pengetahuan Sosial, 7(2), 398-407. Diambil dari http://jurnal.umtapsel.ac.id/index.php/nusantara/article/v iew/1733. 